\title{
Site Specific Backbone Dynamics from a Crystalline Protein by Solid-State NMR Spectroscopy
}

\section{Supplementary material}

Table $1:{ }^{15} \mathrm{~N}$ longitudinal relaxation rates $\left(\mathrm{R}_{1}\right)$ values measured for the different residues in microcrystalline Crh. Experimental conditions are given in the main text (except for residues 35 and 46 , see note). $R_{1}$ values were obtained by fitting the four points to the function $I=I_{0}$. $\exp \left(-R_{1} t\right)$. The experimental intensities were measured from the spectra and renormalized by the average intensity of the two 1s reference spectra recorded before and after each new point. This procedure compensates the data for drift in the CP condition, and improved the fit quality. In all cases, this led to variations of at maximum 5\% in intensities, with correspondingly small variations in $\mathrm{R}_{1}$. Accuracy was then estimated at $\pm 0.005 \mathrm{~s}^{-1}$, except for residues 35 and 46 $\left( \pm 0.01 \mathrm{~s}^{-1}\right)$.

\begin{tabular}{|c|c|c|}
\hline Number & Residue & $R_{1}\left(s^{-1}\right)$ \\
\hline 8 & Val & 0.068 \\
\hline 12 & Thr & 0.036 \\
\hline 13 & Gly & 0.046 \\
\hline $14^{*}$ & Leu & 0.029 \\
\hline 23 & Val & 0.028 \\
\hline 30 & Thr & 0.031 \\
\hline 31 & Ser & 0.070 \\
\hline 35 & Leu & $0.02 * *$ \\
\hline 38 & Asp & 0.129 \\
\hline 39 & Gly & 0.114 \\
\hline 41 & Lys & 0.051 \\
\hline 44 & Ala & 0.048 \\
\hline 45 & Lys & 0.060 \\
\hline 46 & Ser & $0.08^{* *}$ \\
\hline 47 & Ile & 0.032 \\
\hline 49 & Gly & 0.048 \\
\hline 50 & Leu & 0.041 \\
\hline 51 & Met & 0.027 \\
\hline 52 & Ser & 0.053 \\
\hline 54 & Ala & 0.140 \\
\hline 57 & Thr & 0.097 \\
\hline 58 & Gly & 0.032 \\
\hline 63 & Leu & 0.045 \\
\hline 64 & Ile & 0.027 \\
\hline 65 & Ala & 0.033 \\
\hline 67 & Gly & 0.024 \\
\hline 69 & Asp & 0.052 \\
\hline 80 & Tyr & 0.039 \\
\hline 81 & Val & 0.050 \\
\hline 82 & Gln & 0.037 \\
\hline
\end{tabular}

* The $R_{1}$ value for Leu 14 was determined from measurements on the ${ }^{15} N_{L 14} /{ }^{13} C^{\prime}{ }_{G 13}$ crosspeak (not shown in Figure 1).

** Values determined from a previously recorded data set using 2 values with $\tau=1 \mathrm{~s}$ and $15 \mathrm{~s}$. The signal-to-noise ratio in the main data was too weak for these residues to obtain reliable fits. 